\title{
A FLORISTIC STUDY OF REPUBLIC COUNTY KANSAS
}

\author{
by
}

Gordon E。 Morley

B.S., University of Kansas, 1957

Submitted to the Department of Botany and the Faculty of the Graduate School of the University of Kansas in partial fulfiliment of the requirements for the degree of Master of Arts.

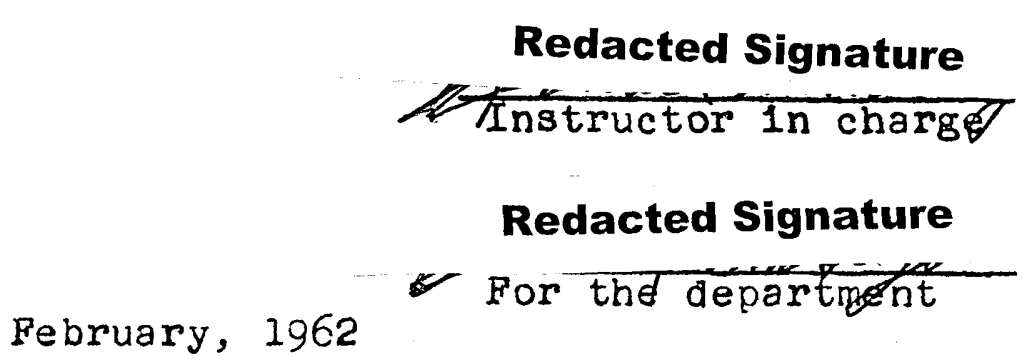


TABLB OF CONTENTS

Page

Introduction........................... 1

Locat1on................................ 2

climate............................... 2

Topography............................. 3

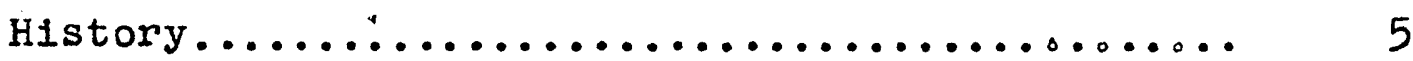

Agriculture and Cultivation.................

Aspects of Areas............................ 8

Grazed prairie pasture in N.W.three-fourths... 8

Prairle in N.W.three-fourths............... 11

Grazed prairle pasture in Dakota sandstone area 13

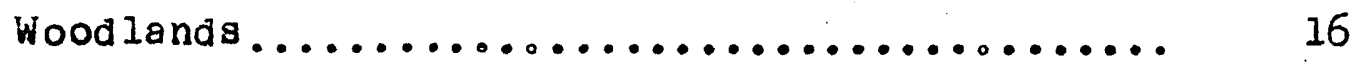

Open woodlands and borders of woods.......... 18

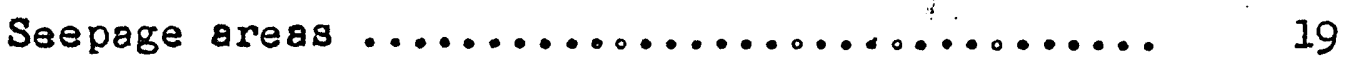

Ponds and pond borders................... 21

Sand bars and river banks................. 22

Annotated species $118 t$

Bibliography 


\section{INTRODUCTION}

The purposes of this study were to obtain a list of the plants presently growing in the county, to discover their assoclations, and to record seasonal aspects of various representative areas.

Hitchcock (1899) listed 251 taxa as occurring in Republic County. Gates (1940) listed 274 taxa for the county. The small difference indicates that most of the collections for the county were made prior to 1900. Th1s study brings the knowledge of the Republic County flora more up to date. 


\section{Location}

Republic County is in the northern tier of counties in Kansas and is about 145 miles west of the Missouri River. It is a rectangle $30 \mathrm{miles}$ east to west and $24 \mathrm{miles}$ north to south. The northern border is at latitude 40 degrees north and the longitudinal meridian 97 degrees 45 minutes passes through the western half of the county. It is bounded on the north by Nebraska, on the east by Washington County, on the south by cloud County, and on the west by Jewell County.

\section{CIImate}

Data for the years 1898-1942, Climate in Kansas (1948), give this information. The average yearly rainfall for the county is 26.52 inches, of which 20.17 inches fall in the seven months between April 1 and September 30. From readings taken at 12:30 PM the average relative humidity is about 53 percent, ranging from a July average of 43.5 percent to an average of 65.6 percent for January.

The mean annual temperature is 53.3 degrees. The temperature reaches over 90 degrees $F$. an average of 61 days per year and goes to 32 degrees F., or below, an average of 132 days per year. The highest temperature recorded is 115 degrees F. reached at Belleville on July 13, 1934. The lowest July temperature was 45 degrees $F$. recorded on July 25,1911 . The highest January temperature ever recorded was 70 degrees on January 26, 1914, (also at later times). The lowest temperature ever recorded was -31 degrees $F$. on February 13, 1905. 


\section{Topography}

The county has three basic types of topography 1 . the loess covered plain in the northern part, 2. numerous alluvial valleys, 3 . deeply dissected uplands.

The loess covered plain covers most of the area included in township one south, ranges two - flve west and also much of the area in township two south, ranges two and three west. The base of this area was formed from the ancestral Republican River channel and valley which entered about five miles south of the northwest corner of the county, flowed eastward crossing the present channel at Republic City, and re-entered Nebraska about half way across the county. This valley was partially filled during the early Pleistocene with coarse sand and gravel. This deposit is the lower portion of the Belleville formation which underlies the loess plains. The river was then forced southward by a glacier but later returned to 1ts original channel and subsequently filled in the upoer part of the Belleville formation. The glacier again forced the channel south where it is presently. After a time a reddish brown silt and clay loess was deposited, and upon this a thin layer of the present soil was deposited. (The reader is referred to Fishel (1948) pages 29-33 for a more complete discussion.)

Most of the alluvial deposits are along the present river valley, with lesser amounts along the small streams, and . Sizeable deposits in the southwest corner in the Jamestown Salt Marsh area and in the Tuthill Salt Marsh area south of Talmo and Wayne. 
The deeply dissected uplands cover most of the area in the eastern one-fourth and southern half of the county. These consist of rough rolling hills with broad to narrow bands or fingers covered with windblown loess between the streams. The relief on the upland bands is often less than 25 feet per mile while the relief in land sloping to the stream valleys is as great as 200 feet per mile and rarely reaches an extreme of 100 feet in one-eighth of a mile. Along the cuts made by the streams one can observe the underlying rock formations which (except for the southeast corner) are (beginning with the upper layer) Carlile shale, Greenhorn IImestone, and Granerous shale. The lower Dakota formation of sandstone, sandy shales, and clay underlies the whole county and is exposed in the southeastern quarter of the county where it is the parent material for the soll.

The Republican River enters at the northwest corner and exits about eight miles east of the southwest corner. It drains all of the county except the northeast fourth which is drained by Rose Creek and MIII Creek. The streams in the western twofifths of the county flow southeast if on the west side of the river and flow southwest if on the east side of the river. The streams in the central and southeastern parts drain generally southward, turning a little southeast in cloud County before emptying into the Republican River as it flows eastward along northern Cloud county. Rose Creek drains the northwestern half of the northeastern fourth of the county but flows to the northeast, emptying into the Little Blue River in Nebraska. M1II 
Creek drains the southeastern half of the northeast fourth and flows east into Washington County where it also empties into the Little Blue River.

One sees from the drainage pattern that the county slopes generally from the northwest to the southeast; the highest area being near the Nebraska IIne with a maximum elevation of 1640 feet above sea level and the lowest point being about two and one-half miles west of the southeast corner with an elevation of about 1320 feet.

\section{History}

From materials the author has read the county was basically rolling high prairle interrupted by belts of woodland along the streams and by two large salt marshes, the Jamestown Marsh in the southwest corner and the Tuthili Marsh south of Talmo and Wayne.

The oldest reference to the vegetation of the county, the author found, was a series of articles derived from the journal of Augustus Ford Harvey, one of a surveying party which began working in Republic County in October, 1858. These were published as weekly installments in the Belleville Telescope June 30 through August 18, 1960. The original notes are on file in the Marshall County court house, Marysville, Kansas. In the July 7 th article he described one prairie plant as having a beautiful pink, round flower about three fourths inch in diameter. The leaves closed when touched, and the plant looked to him like a locust, but his companions called it "sensitive 
rose". This was very likely Schrankia nuttalli1 (D.C.) Standl. In the July 21 article he described one area somewhere along the Republican River as having tangled wlllow thickets and thick, head high grass. In the July 28 article he mentions very deep and tangled grass one to three feet above their heads as occurring in township 4 south, range 4 west. The party probably was in lowland prairie near the Republican River. Harvey, in the August 11 issue, reports the Jamestown Salt Marsh covered 30,000 acres. Perhaps there was an error somewhere, since the original land plats in 1859 show an estimated 3,000 to 4,000 acres.

The original land survey notes, 1858-59, reveal more information about the early history of the county. The writer of these describes the land as rolling prairie and mentions the following as occurring along streams: hackberry (Celtis occidental1s L.), black walnut (Juglans nigra L.), burr oak (Quercus macrocarpa Mich.), willows (Salix amygdaloldes Anderss. and Salix Interlor Rowlee), cottonwood (Populus deltoldes Marsh and Populus sargenti1 Dode), e Im (UImus americana L. and Ulmus rubra Muh1.), ash (Fraxinus pennsylvanica Marsh), mulberry (Morus rubra L. and Morus alba L.), box elder (Acer negundo L.), honey locust (Gleditsla tricanthos L.), prickly ash (Xanthosylum americanum M111.), and swamp dogwood (Cornus drummond1 C.A. Meyer). He also mentions briars and vines in the underbrush. The author is inclined to believe that the "briars" were elther Ribes missourlense Nutt. and, or Smliax tamnoides L. var. 
hisplda (Muh1.) Fern. and that the vines referred to V1tis riporia Mich., S1cyos angulatus L., or Parthenocissus quinguefolla (L.) Planch.

I. O. Savage (1901) in writing of the early history of Republic County estimated that ten percent of the land was river and creek bottoms and ninety percent was high prairie. He estimated that along the streams there were ten to elghty rods of timber composed of ash, black walnut, hackberry, red and white elm, box elder, cottonwood, and ook. Black walnut, ash, elm, and maple (Acer saccharinum L. ?) were also being planted in groves by the settlers.

\section{Agriculture and Cultivation}

The basic agriculture of the county is corn, wheat, milo, hay, cattle, and hogs. In 1941 about 61 per cent of the total acreage was in cultivation; pastures and "prairies" occupled about 25 per cent; woodlands occupied about 3.5 per cent, with the rest in miscellaneous non-agricultural uses. Nearly two-thirds of the cultivated land showed moderate to extreme erosion. (Eroded pastures were in addition to this). One can see from this that the upland vegetation is much changed from its orlginal high prairie situation. True original prairies are non-existent, but there are some prairie hay fields scattered throughout which are mostly untillable bills or slopes. A few of these sometimes go a year or two without being mowed. 


\section{Aspects of Areas}

The aspects of the various areas are based mostly upon the author's collections and observations. These aspects are considered by the author to be falrly complete; however, 1t is belleved that further studies would modify these descriptions slightly.

Grazed prairie pastures in the northwestern three-fourths of the County are basically composed of Buchloe dactyloldes with lesser amounts of Poa pratense, Bouteloua hirsuta, Bouteloua curtipendula, with Andropogon scopar1us in some.

The spring aspect is characterized by the following: Bromus tectorum and Bromus japonicus are very numerous and w1despread, while Poa pratense appears in numerous scattered cumps and Festuca octoflora and Sphenophilus obtusata are only sparsely scattered. Androsace occldental1s is quite numerous and widespread although not very evident. Carex brevior is is fairly numerous and extensive on the more level areas while Plantago purshi1, Plantago v1rginica, and Antennaria campestris each appear as scattered colonies although often numerous within the colony. Callirhoe alcaeoldes, Lithospermum incisum and Agoseris cuspidata occur sparsely scattered but are falrly evident. Astragalus missouriensis and Senecio plattensis are common on limestone outcrop slopes or hills; Lomatium foeniculatum is less common, while Allium drummondi and Townsendia exscapa are sparsely scattered on limestone areas.

Present, but less consistent and characteristic, are 
Allium perdulce, Anemone caroliniana, Carex gravida, Carex gravida var. Iunelilana, Silene antirrhina, Viola bicolor, Draba reptans, Astragalus plattensis, Astragalus caryocarpus, Plantago rhodosperma, Taraxacum officinale, Taraxacum erythrospermum, and Sisyrinchium campestre var. kansanum.

The early summer aspect of a grazed prairie pasture is characterized by the following specles imposed on the basic structure: Bromus japonicus is numerous, scattered and widespread, while Poa pratense occurs in numerous scattered clumps; Buchloe dactyloldes extends over large patches; and Agropyron smithi1, Bromus squarrosus, Psoralea argophylla, and Plantago purshil are present as scattered colonies. Hordeum pusillum and Juncus interior are common and scattered, while Sphenophilus obtusata, Cyperus filiculmis, Festuca octoflora, Relygala verticlilata, and Achillea lanulosa are sparsely scattered more or less throughout. Verbena stricta, Erigeron strigosus, Linum sulcatum, Linum riglaum, and Hymenopappus tenuifolius occur somewhat numerous and scattered. EchInacea augustifolia is very common on limestone hills, while Penstemon Cobaea, Denothera serrulata, Ratibida columnifera, and Polygala alba occur commonly on limestone hills but not so numerous as $\underline{E}$.. ausustifolia. Oenothera missourlense appears evident but occurs scattered on these stony places.

Others present but less characteristic are Carex gravida, Carex gravida var. Iunelliana, Carex brevior, Specularia perfoliata, Specularia leptocarpa, Silene antirrhina, Hedyotus 


\section{nigricans, Plantago rhodosperma, Plantago virginica,}

Schedonnardus paniculatus, Delphinium virescens, Caliirhoe alcaeoides, Caliirhoe involucrata, Euphorbia dictyosperma, Soermoledis inermis, Opuntis humifusa, Psoralea esculenta, Clrsium undulatum, Cirsium vulgare, Haplopappus spinulosus var. Elaberrima, Hymenopappus f1lifolius, Tragopogon dubius, The lesoerma megapotamicum, Hedeoma hispida, Verbena bipinnatiflda, Psoralea tenuiflora, Schrankia nuttalli, Taraxacum officinale, and Taraxacum erythrospermum.

The late summer aspect of this grazed prairle pasture is characterlzed as follows: The most evident specles are Verbena stricta and Euphorbia marginata which are common and scattered over much of the pasture while Vernonia baldwinl1 var. interior is the most evident on the lower levels of the pasture. Closer examination reveals Bouteloua hirsuta and Bouteloua curtipendula, to be quite common with Bouteloua grac111s, Sporobolus cryptandrus, Ambrosia psilostachyo var. coronop1folia, and Artemisla ludoviclana var. gnaphalodes to be common but less so than the other two. The limestone outcrop slopes and hills also have scattered Polygala alba and Stenosiphon linifolius.

Present in some of the pastures but not as characteristic are Andropogon scoparius, Gerardia aspera, Grindellia squarrosa, Haplopappus splnulosus var. glaberrima, Cirsium vulgare, Erigeron strigosus, Erigeron canadensis, Lactuca scar1ola, Linum rigidum, Linum sulcatum, Polygala verticillata, 
Malug vert1c11lata, Euphorbia glyotosperma, Solanum caroInense forma albiflorum, Psoralea tenulflora, Petalostemum purpureum, Petalostemum candidum, Lactuca scariola, Lotus americanus, Verbascum thaspus, Taraxacum officinale and Taraxacum erythrospermum.

The fall aspect of the grazed prairle pasture 18 characterized as follows: Bouteloua hirsuta and Bouteloua curtipendula are the most common grasses with Bouteloua grac111s, Eragrost1s spectab1lis, and Sporobolus cryptandrus common but less so than the first two.. On the more level areas Euphorbia marginata is evident and common but is scattered throughout. On the IImestone hills or outcrop areas Solidago rigida is numerous and present along with it are some Iiatris punctata and Iiatris aspera.

Also present but less characteristic are Andropogon scoparius, Grindel11a squarrosa, Kuhnia eupatorioides var. corymbulosa, Eupatorium alt1ssimus, Solidago canadensis var. scabra, and Verbena stricta.

A representative prairie in the northwestern threefourths of the county is generally on a thin soiled hill or slope and mowed almost every year. The basic grasses present are Andropogon gerardi and Andropogon scoparius along with lesser amounts of Sorghastrum nutans, Panicum virgatum, Bouteloua hirsuta, Bouteloua curtipendula, and Poa pratense. The following give the appearances of the area at the designated times.

The spring aspect of the prairie is characterized as follows: Bromus japonicus and Poa pratense are numerous, 
widespread, and evident; while Sphenophilus obtusata appears In scattered clumps and Koeleria cristata in yet fewer and smaller scattered clumps. Sisyrinchium campestre var. kansanum is common and widespread. Allium drummond1 is commonly scattered within large colonies while Draba reptans is common but not evident. Agoseris cuspidata and Lomatium foeniculatum are scattered but evident. Near the end of the spring aspect Penstemon Cobaea becomes common.

The early summer aspect is characterized as follows: Poa pratense, Bromus japonicus, and Sphenophilus obtusata are st111 present but are being replaced by other species. Panicum scribnerlanum is falrly numerous and extensive as also is Hedyotus nigricans. Echinacea augustifolia is quite evident and fairly numerous with Penstemon Cobaea, Denothera serrulata, Delphinium virescens, Polygala, alba, Petalostemum purpureum, and The lesperma megapotamicum being less numerous, but st111 evident. Oenothera missouriense is evident but not very numerous and Amorpha canescens is present in colonies.

Others found but less characteristic are Erigeron str1gosus, Festuca octoflora, Koeleria cristata, Tragopogon dub1us, Ach1llea lanulosa, Schrankia nuttall11, Haplopappus sp1nulosus var. glaberrima, Ratibida columnifera, Elymus canadensis var. brachystachys, Petalostemum cand1dum, Lotus americanus, Buchloe dactyloldes, and Psoralea tenulflora..

The late summer aspect of the prairie is characterized as follows: Potaiostemum purpureum, Dalea aurea, Dalea enneandra, Stenosiphon Inifolius, and Salvia azurea var. 
grandiflora are all evident but not actually very numerous. There is some Andropogon gerard1, Andropogon scoparius, Panicum virgatum, Aster oblonglfolius, Llatris punctata var. nebraskana, and Liatris aspera in early flower. Bouteloua hirsuta and Bouteloua curtipendula are fairly numerous and widespread.

Other species present but less characterist1c are: Thelesperma megaootamicum, Denothera serrulata, Petalostemum candidum, Psoralea tenuiflora, Lotus americanus, Solidago missoufense var. fasclculata, S1lphium speciosum, and Aster sericeus.

The fall aspect of the prairie is characterized as follows: Andropogon gerardi and Andropogon scoparius ane numerous, evident, and extensive with some Sorghastrum nutans and Panicum virgatum scattered among them. Aster oblongifolius is somewhat common along with Liatris punctata var. nebraskana, and Liatris aspera. There are also scattered Hellanthus maximiliani and a few small groups of Silphium speciosum. Bouteloua hirsuta and Bouteloua curtipendula are about gone by and are definitely obscured. Found but less characteristic. are: Solidago missouriensis var..fasclculata, Helianthus laetiflorus var. rigldus, and Aster sericeus.

The grazed prairie pasture in the Dakota sandstone area of the county is overlaid by thin sandy loam with outcroppings of sandstone in places. The basic structure of the pasture is Andropogon scoparius, with considerable Poa pratense, and some 
Bouteloua hirsuta, and Bouteloua curtipendula.

The spring aspect is characterized as follows: Bromus japonicus, Poa pratense, and Panicum scribnerianum are numerous widespread and evident. Carex brevior and Tradescantia occidentalis are common but scattered on the more level areas. Agrostis hiemalis is scattered in clumps. Cerastium brachypodium and Androsace occldentalis are numerous and scattered but not very evident. Hymenopappus tenuifolius is coming into flower in large colonies. Tradescantia tharpil is common and scattered on the sandstone outcrop areas.

Also present but not as characteristic are: Linum sulcatum, Linum rigidum, Panicum huachucae, Carex gravida, Carex gravida var. Ilunelilana, Astragalus plattensis, Oenothera serrulata (early), Asclepias nuttalliana, Silene antirrhina, Haplopappus spinulosus var. glaberrima, Festuca octoflora and Asclepias viridis.

The early summer aspect of this Dakota area grazed prairie pasture is characterized as follows: Panicum scribnerianumi and Bromus japonicus are numerous and widespread. Erigeron strigosus and Hymenopappus tenu1folius are numerous w1th large colonies. Carex brevior and Tradescantia occidentalis are scattered on the more level areas while Agrostis hiemalis is scattered in clumos throughout.

Others found but less characteristic are: Linum sulcatum, Linum rig1dum, Carex gravida, Carex gravida var. Iune 111ana, Panicum huachucae, Oenothera serrulata, Opuntia humifusa, 
Festuca octoflora, Argemone intermedia, Psoralea argophylia, Ach1llea lanulosa, Agropyron smithil, Tragopogon dubius, Haplopappus spinulosus var. glaberrima, Astragalus plattensis (in fruit), Juncus Interior, C1rsium undulatum, Verbena stricta and Polygala verticillata.

The late summer aspect of the grazed prairie pasture in the Dakota area is characterized as follows: No one species appears to be very numerous or evident. Cirsium undulatum, Verbena stricta, Achillea lanulosa, Iinum sulcatum, Iinum rigidum, Vernonia baldwini1 var. interior, Polygala verticillata, and Lotus americanus in the forepart of late summer each have a few scattered which are in flower. In the latter part of the late summer aspect Verbena stricta, Vernonia baldwini var. Interior, Polygala verticlilata, and Lotus americanus are still in flower. Scattered Euphorbia marginata, Heterotheca latifolia var. McGregor1s, Panlcum virgatum, Muhlenbergia asperifolia, Solidago missouriensis var. fasciculata, Bouteloua hirsuta, Bouteloua curtipendula and Grindellia squarrosa appear at this time.. Numerous and scattered in the pasture but just beginning to come out are Andropogon scoparius, Ambrosia psilostachyo var. coronopifolia and Artemisia ludoviciana var. gnaphalodes, Artemisia ludoviciana var. Iudoviclana is present but very sparse, and Panicum scribnerianum is still present but is obscured.

The fall aspect for the grazed prairie pasture in the Dakota area has not been well collected but the following is 
a sketch based on a few collections and observations. The most prevalent and evident species is Androoogon scoparius; however Ambrosia psilostachya var..coronopifolia and Artemisia Iudoviciana var. gnaphalodes are very common and widespread.. There are a few scattered Liatris punctata var. nebraskana, Grindeliia squarrosa, Heterotheca latifolia var. McGregoris, Euphorbia marginata, Leptoloma cognatum, Eraxrostis spectabilis, Artemisia ludoviciana var. Iudoviciana, Verbena stricta, Muhlenbergia asperifolia and Solidago missouriensis var.. fasciculata. Gerardia tenuifolia var. macrophylla occurs in a few dense colonies.

The woodlands in the county almost all occur along the river and along the streams. Present in the woodlands one flnds these trees: Acer negundo var..violaceum, Juglans nigra, Fraxinus pennsylvanica var. subintegerrima, Fraxinus pennsylvanica var. alistini (rare), Ulmus americana, UImus rubra, Celtis occidentalis var. pumila, Celtis occidentalis var. occldentalis, quercus macrocarpa, Gleditsia trichanthos, Morus rubra, and Morus alba. Also present but not very numerous are Gymnocladus diolca and Catalpa speciosa.. These may not all be found at one time but occur in varying numbers in different localities with few set patterns.

Salix amygdaloides, Salix interior, Populus deltoides, and Populus sargentil make up most of the border along the river along with an occasional Salix nigra.

The spring aspect of woodlands is characterized as follows: 
Parthenocissus quinquefolia is present either numerous and growing on the floor or as a few vines climbing the trees. Ribes missouriense is common and flowering, with Vitis riparia present as a few climbing vines. Smilacina stellata (not very often), Polygonatum canaliculatum, and Viola papilionacea occur as groupsjor singly. Galium aparine, Sanicula canadens1s, and Ellisia nyctelia are often present, but are not numerous.

The early summer aspect of woodlands is characterized by: Geum canadense var. camporum, Sanicula canadense, and Oxalis stricta are fairly common and scattered; Parletaria pennsylvanica and Elymus virginicus var. jejunis are present as large colonies of each; covering much of the floor of the woods in some areas. R1bes missouriensis is common and in fruit. Smilacina stellata and Polygonatum canaliculatum are in fruit.

The late summer herbaceous aspect of woodlands is of ten characterized by: Parietsria pennsylvanica and Elymus virgin1cus var. Jejunis covering conslderable floor area while Urtica dioica var.. procera is in dense extensive colonies. Sicyos angulatus has vined considerably and is in flower and early fruit. Sanicula canadense, Geum canadense var. camporum and Oxalis stricta are in late flower and fruit; and Smilacina stellata and Polygonatum canaliculatum are in late fruit. Solanum americanum, Chenopodium boscianum, Hackelia virginiana, and Teucrium canadense var. virglnicum are scattered. 
Menispermum canadense occurs occasionally, and polygonum punctatum occurs in a few colonies.

The woody vines, Vitis riparia and Smilax tamnoldes var. hisplda occur as scattered climbing vines and have ripening fruit, while Rhus radicans occurs both as a prostrate and cliribing vine - also in fruit.

The fall aspect of the woodlands is characterized basically by the maturation and final fruiting of the late summer species with the addition of Solidago gigantea scattered in the river woodlands.

The early summer aspect of open woodlands and woodland borders is characterized as follows: Verbena urticifolia and Oxalis stricta are the most common and characteristic. Cornus drummond1, Hackelia virginiana, Sambucus canadensis and Physal1s heterophylla occur fairly commonly in groupsior scattered.

Others which occur but are not as characteristic are: Conium maculatum, Plantago rugell11, Plantago major, Rubus occidentalis, Rumex crispus, Rumex altissimus, Lappula echinata, X Verbena Engelmanni1, X Verbena Rydberg11, X Verbena 1 lliclta, (these three Verbena hybrids occur together in a semi-wooded pasture along a stream), Ruelila humilis, Xanthoxylum americanum (in fruit), Thallctrum dasycarpum (in fruit), Teucrium canadense var. virginicum, Phryma leptostachya, Nentha arvense var. villosa forma glabrata, Lycopus americanus, Carex granularis, and Ellisia nyctelia. 
During late summer in open woods and along the borders of woods the following may be found: Urtica diolca var. procera, Cannab1s sat1va, Actinomeris alternifolia and Verbena urtic1folia, each of which occurs in patches of 1tself falrly common1y. Oxal1s stricta occurs commonly scattered as does Hackella virginiana (Hackelia a little less numerous). Those which occur less commonly or even singly are: Symphorocarpos orbiculatus, Arctium minus, Acaljoha rhomboldea, Lobel1a splendens (by streams), Xanthoxy lum americanum (fru1t), Penthorum sedo1des (by stream), S1da spinosa, Alisma triviale (edge of stream), Mentha arvense var. villosa formaglabrata, Mimulus ringens (mo1st alluvium) Lycopus americanus, Solidago g1gantea, Verbena hybrids, Lactuca canadense var. f1l1folius, Monarda f1stulosa var. moll1s, and Cornus drummond1 (fruit).

The fall aspect of the woodland edges and open woods bas1cally is the maturation of the late summer specles along with the addition of some scattered Muhlenbergis frondosa, B1dens vulgata and Bidens frondose.

In many of the draws and ravines in the hilis and occasionally elsewhere there are springs or seepage areas. Some of these are very small; while others are large enough to keep a large area in marshy condition; and occasionally one is large enough to provide water for a household. Sometimes these springs are dammed up, making a pond generally used for watering cattle and for flshing. The only woody perennials which regularly grow on these areas are Salix interior, and Salix amygdaloldes, which occur more often on the larger marshy area. 
The early summer aspect of these marshy areas in general 1s characterized as follows: Sclrpus americanus and Typha latifolla occur in large and small groups which are quite exclusive of other specles. Eleocharis palustris commonly occurs in very shallow water or along the border of the marsh; of ten growing between or under the larger sized specles. Sclrpus atrovirens, Scirpus validus, Carex lasiocarpa var. lat1fol18, Juncus torrey1, and Verbena hastata occur common to scarce but are scattered. Carex vulpinoldea is common in clumps around the edges of the marsh.. One may also at times find: Phalar1s arundinacea, Rumex crispus, Rumex altissimus, Rorippa sessiliflora, Ror1ppa sinuata, Equisetum leev1gatum, Equisetum kansanum, Ranunculus scleratus, Potent1lia paradoxa, Berula pus111a, Hordeum Jubatum, Acorus calamus, Sphenoph1lus obtusata, Carex normilis, Trifolium repens, Agrost1s alba, Clcuta maculata, Polygonum persicarla var. ruderale, Mentha arvense var. v1llosa forma glabrata, Lycopus amer1canus, Teucrium canadense, spargantum eurycarpum, Lemna minor, Lemna perpus111a, and Splrodelia polyrhiza. Specles which are found only in the Dakota sandstone areas are: Glyceria striata; somewhat common and scattered; Carex scoparia and Carex hystricIna In scattered clumps in one area; Juncus tenuis, found scattered at the edge of one location with Juncus marginatus common in the seepage areas.

The late summer aspect of the generalized seepage areas is characterized as follows: Echtrionloa crusgalli, Polygonum 
lapathifolium, Polygonum pennsylvanicum var. pennsylvanicum, Cyperus strigosus, and Juncus torrey1 are common and are of ten In separate groups. Not too numerous but evident are Verbena hastata (numerous in the sandstone areas), Ascleplas incarnata, and Bidens glaucescens. Sagittarla latifolia var. lat1folla and Sag1ttaria brevirostra occur commonly in the shallow water. Also present at times are: Polygonum punctatum var. leptostachyum, Polygonum hydropiperoldes, Eclipta alba, Setarla Glauca, Scutellaria laterifolia, Ranunculus scleratus, Potent1lla paradoxa, Berula pus1lia, Sag1ttar1a Engelmanniana, Sag1ttaria laterifolia var. obtusa, Epilobium coloratum, Lemna minor, and Spirodelia polyrhiza.

Occuring only in sandstone seepage areas (at least accordIng to present collections) are: Lobelia s1ph1litica, Hyper1cum mutilum, and Piles pumila (a few of each), and numerous scattered Agrimonia parviflora.

The fall aspect of the seepage areas is basically a maturation of the late summer species along with the addition of numerous Iva annua, Ambrosia trif1da, and Leersia oryzo1des and some Aster simplex and Aster praealtus.

There are severol ponds in the County which have been made by placing a small earthen dam across a draw or small ravine. These may be filled by run-off water or by a combination of run-off water and spring water. In these one somet1mes finds Potamogeton follosus common, Potamogeton nodosus common In two ponds, Potamogeton pectinatus, some found in one pond, 
and Ceratophyllum demersum, common in one pond. The following found in or around ponds flower in early summer: Bacopa rotundfolis, numerous in shallow vater of one pond and Heteranthera 11moss, numerous around the edge of one pond. Rorippe sess1Ifflora and Eleochoris palustris are common in very shallow water along the edges.

In the late summer and fall one sometimes finds in addition to the above: Ammania coccinea, Echinodorus rostratus, Cyperus erythrorhizus, and Heteranthera Iimosa (not flowering). Each has been found in only one location but was common along the edges of the pond where 1t was found. Sagittaria latifolia var. latifolia is common in shallow water along the edge of at least two ponds and Sagittaria graminea (not found in flower or fruit) is scattered in the fairly shallow water of one pond. A group of Polygonum coccineum var. rigidulum is present in one pond.

Very little blooms on the sand bars and river banks in the spring besides Sal1x 1nterior, Sal1x amygdaloides, SaI1x nigra (scottered), Populus deltoldes, and Populus sargentil. In early summer one also finds Scirpus validus, a little Juncus torrey1, some Rorlppa sessiliflora, Rorlppa islanalca, Rumex alluvius, Rumex maritimus and Apocynum cannabinum, plus a few Iindernia anagallidea. By late summer the Rorlppa specles are gone by, and Rumex alluvius is almost all brown. Occasionally present, then, are MImulus ringens, Scutellaria laterifolia, and Penthorum sedoldes. Numerous in places are Iva annua and Apocynum cannabinum (fruit). Xanthium pennsylvanicum is bloomIng at this time。 


\section{Annotated List}

The following list of 581 taxa includes those collected in Republic County by the author in 1960-61. Included in addition to these are a few species collected by Dr. W. H. Horr of Kansas University in 1953, and one species collected in 1960 by Donald Guyer of Belleville. A1so included are the names of taxa 1isted by Weaver and Albertson (1943), Gates (1940), and Schaffner (1898), which were not found by this author. Each of this group of 66 taxa is indicated by placing the particular author's name and the publication date after the name of the taxon. A number of taxa which the author did not collect were 1isted by Gates (1940) for one or more of the neighboring Kansas counties; Jewe11, Mitche11, Cloud, Clay, and Washington; but these taxa are not included in this 1ist.

About 67 of the taxa included in this 1ist were not reported by the above named authors as being present in the six county area. One species, Juncus Bufonius L., has not been previously reported for Kansas.

The families are listed alphabetically as are the genera and the species within a family.

The nomenclature follows the eighth edition of Gray's Manual for most of the families. The nomenclature in the Compositae, Cyperaceae, Juncaceae, Umbelliferae, Polygonaceae, and Equisetaceae follows the third edition of Britton and 
Brown (An I11ustrated F1ora of the Northeastern United States and Adjacent Canada, 1952). The nomenclature in the Oxa1idaceae follows George Eiten of the New York Botanical Garden, in the genus Allium follows Marion Ownbey (A11ium Canadense and Its Allies in North America), in the genus Physalis follows U. T. Waterfal1 (Monograph of the Genus Physalis) and in the genus Asclepias follows Woodson (North American Species of Asclepias). For some of the species not covered by the above publications the nomenclature follows Rydberg (F1ora of the Prairies and Plains of Central North America, 1932). Some of the species listed by Gates (1940) are not covered by other authors and are here on his authority. 
Acanthaceae

Ruel1ia humilis Nutt. var. frondosa Fern.--sparse woodlands along creek

Aceraceae

Acer negundo L. var. violaceum (Kirsch) Jacq.--woodlands along streams

Acer saccharinum L.--group found on wooded farm 1 ot Aizoaceae

Mo11ugo verticillata L.--sandy waste or disturbed areas A1ismaceae

Alisma triviale Pursh.--partially shaded edges of sma11 streams

Echinodorus rostratus (nutt.) Enge1m.--shores of ponds Sagittaria 1atifolia Willd. var. 1atifolia--edges of slow streams and ponds, marshes

Sagittaria 1atifolia Willd. var. obtusa (Muh1.) Wieg. marshy area

Sagittaria brevirostra Mack. and Bush.--same as preceding

Sagittaria graminea Michx.--seepage pond

Amaranthaceae

Amaranthus albus L.--sandy roadside

Amaranthus arenicola Johnst.--waste areas

Amaranthus b1itoides S.Wats.--sandy waste area, pasture draw

Amaranthus retroflexus (Gray) Benth.--roadsides, fields, waste p1aces 
Amaranthus tamariscina Nutt.--waste areas and in salt $\operatorname{marsh}$

Amaranthus ch1orostachys Wi11d.--Schaffner, 1898

Froelichia gracilis (Hook.) Moq.--sandy waste area

near R.R. station

Amary11idaceae

Sisyrinchium campestre Bickn. var. kansanum Bickn.-grazed pastures and prairies

Anacardiaceae

Rhus glabra L.--overgrazed pastures, roadsides, R.R. right-of-ways, draws

Rhus radicans L.--woods, roadsides, draws Apocynaceae

Apocynum androsaemifolium L--Weaver and Albertson, 1943 Apocynum cannabinum L.--roadsides, waste p1aces Apocynum sibiricum Jacq.--same

Araceae

Acorus calumus L.--wet seepage areas Asc1epiadaceae

Asclepias amplexicaulis Smith--Weaver and A1bertson, 1943

Asclepias asperula (Decne) Woodson ssp. capricornu

(Woodson) Woodson--Weaver and A1bertson, 1943

Asclepias incarnata $L$. var. incarnata--wet seepage areas Asclepias 1atifolia (Torr.) Raf.--Weaver and Albertson (1943) 
Asclepias nuttalliana Torr.--few on sandstone pasture Asclepias pumila (A.Gray) Vail--Gates 1940

Asclepias speciosa Torr.--sandy roadsides, R.R. rightof-way, salt marsh prairie

Asclepias stenophy11a A.Gray--roadside

Asclepias sullivantii Enge1m.--roadsides in sandstone area, salt marsh prairie

Asclepias syriaca L.--roadsides, waste places, cultivated fields

Asclepias verticillata L.--salt marsh prairie, also on roadsides

Asclepias viridiflora Raf.--prairies, pastures, and roadsides

Asclepias viridis Wa1t.--grazed pastures, roadsides Bignoniaceae

Catalpa speciosa Warder.--Woodlands and cultivated as ornamentals and shade

Boraginaceae

Hackelia virginiana (L.) Johnst.--woods

Lappula echinata Gilig.--edge of woods

Lappula occidenta1is (S.Wats.) Greene-R.R. right-of-way

Lithospermum incisum Lehm.--grazed pasture

Onosmodium occidentale Mack.--grazed pasture limestone outcrop 
Cactaceae

Neomammilaria missouriensis (Sweet) Britt. and Rose-in Gates 1940

Opuntia humifusa Raf.--grazed pastures

Campanu1aceae

Specularia 1eptocarpa (Nutt.) Gray--grazed pastures

Specularia perfoliata (L.) A.D.C.--waste places and grazed pastures

Capparidaceae

C1eome serrulata Pursh--Gates 1940

Cristate11a jamesii T. \& G.--Gates 1940

Polanisia trachysperma T. \& G.--Gates 1940

Caprifoliaceae

Sambucus canadensis L.-edge of woods and roadsides

Symphoricarpos occidentalis Hook.--slopes of river b1uffs pasture

Symphoricarpos orbiculatus Moench.--draw slopes and edge of woods

Caryophy11aceae

Cerastium brachypodum (Enge1m.) Robins--grazed sandstone pastures

Paronychia jamesii T. \& G.--high 1imestone hills pasture

Saponaria officinalis L.--escaped and escaping along roadsides

Silene antirrhina L.--grazed pastures 
Ste11aria media (L.) Cyri11a--1awns

Celastraceae

Celastrus scandens L.--edge of woods and in thickets Ceratophy11aceae

Ceratophyllum demersum L.--deep spring fed pond Chenopodiaceae

Atriplex argentea Nutt.--edge of salt marsh flats

Atriplex patula L. var hastata (L.) Gray--same

Bassia hyssopifolia (Pa11.) Ktze.--waste areas, cu1tivated fields, roadsides, etc.

Chenopodium album L.--waste areas and roadsides

Chenopodium ber1anderi Moq.--dry soi1--Gates 1940

Chenopodium boscianum Moq.--woods

Chenopodium hybridum L. var. gigantospermum (Ae11en)

Rouleau--woods and waste places

Chenopodium incanum (S.Wats.) Heller--dry ground--Gates 1940

Chenopodium leptophy11um Nutt.--roadsides and waste areas

Cyc1oloma atriplicifolium (Spreng) Cout.--roadside along river bottom 1 and-sand

Kochia scoparia (L.) Schrad.--waste places, fields, and roadsides--Gates 1940

Monolepis nutta11iana (Schu1tze) Greene--waste areas Salsola Kali L.--mainly on slopes of river bluff ravines 
Suaeda depressa (Pursh) S.Wats.--salt marsh flats Comme1inaceae

Commelina communis L. var Iudens (Mique1) C.B. C1arke-somewhat shaded unmowed areas of yards and edge of one woodland

Tradescantia bracteata Sma11--pastures and roadsides Tradescantia occidentalis Britt. \& Smyth--sandy roadsides and sandstone pasture

Trandescantia tharpii Anders. \& Woodson--grazed sandstone pastures

Tradescantia virginiana $L_{---s a n d y}$ roadside Compositae

Achillea lanulosa Nutt.--prairies, grazed pastures, roadsides

Achillea occidentalis Raf.--Weaver and A1bertson, 1943 Actinomeris alternifolia (L.) D.C.--edge of woods, in open woods

Agoseris cuspidata (Pursh) Raf.--1imestone hil1s in grazed pastures and prairies

Ambrosia artemisiifolia L. var. elatior (L.) Descoutils) - -grazed pasture and roadsides

Ambrosia psilostachya D.C. var. coronopifolia (T.\& \&.) Farw.--roadsides, fields, waste places, yards, grazed pastures

Ambrosia trifida L.--marshy areas, edge salt marsh flats 
Antennaria campestris Rydb.--grazed pastures Arctium minus (Hi11) Bernh.--open woods and edge of woods

Artemisia campestris caudata (Michx.) Ha11 \& C1ements-Gates, 1940

Artemisia ludoviciana Nutt. var. gnaphalodes (Nutt.)

T. \& G.--pastures

Artemisia 1udoviciana Nutt. var. Iudoviciana--roadsides and pastures

Aster ericoides L.--grazed pastures roadsides, and waste places

Aster ericoides L. forma caeruleus (Benke) Blake--roadside bank

Aster oblongifo1ius Nutt.--prairies and roadsides

Aster praealtus Poir.--edges of moist woods

Aster sericeus Vent.--prairies, sandstone pasture

Aster simplex Wi11d. var. ramosissimus (T. \& G.) Cronq. --edge of salt marsh flats

Aster sagittifolius Wedemeyer var. Drummondii (Lind1.) Shinners--one found in alley

Bidens bipinnata L.--unmowed areas of yards

Bidens frondosa L.--seepage areas, shaded stream bank Bidens glaucescens Greene--seepage or low wet places, moist woods

Bidens vulgata Greene--seepage areas, 1ow wet places, moist woods 
Chrysopsis ballardi Rydb.--river bluffs pasture (sandy) Chrysopsis hirsutissma Greene--river bluffs pasture Cirsium a1tissimum (L.) Spreng.--waste places, grazed pastures, and roadsides

Cirsium flodmanii (Rydb.) Arthur--Gates, 1940

Cirsium ochrocentrum A. Gray--Gates, 1940

Cirsium undulatum (Nutt.) Spreng var. megacephalum

(Gray) Pern.--grazed pastures

Cirsium undulatum var. undulatum (Nutt.) Spreng--grazed pastures

Cirsium vulgare (Savi.) Tenore--thick in shallow draws of pastures and fields, becoming a real pest.

Coreopsis tinctora Nutt.--wheat stubb1e

Dyssodia papposa (Vent.) Hitchc.--bottom and sides of river bluff ravines

Echinacea angustifolia D.C.--1imestone outcrops in prairies, pastures, etc.

Eclipta alba (I.) H.S.S.K.--edge of pond and on grave1 edge of a spillway stream

Erigeron annuus (L.) Pers--pastures

Erigeron canadensis ( $L_{.}$)--roadsides, waste places, fields

Erigeron divaricatus Michx.--edge of dry 1awn Erigeron strigosus Muh1.--roadsides, grazed pastures, prairies

Eupatorium altissimum L.--roadsides, pasture 
Eupatorium rugosum Geutt.--woodlands

Euthamia gymnospermoides Greene--Gates 1940

Gaillardia pulchel1a Foug.--Gates 1940

Gnaphalium obtusifolium L.--salt marsh prairie

Grindellia squarrosa (Pursh) Duna1--dry grazed pastures Haplopappus spinulosus (Pursh) D.C. var. glaberrima

$\left(R y d b_{0}\right)$ Blake--grazed pastures and prairie

Helianthus annuus L.--roadsides, fields, waste places Helianthus grosseserratus Martens--Gates 1940

Helianthus hirsutus--few along roadside

He1ianthus laetiflorus Pers. var. rigidus (Cass) Fern.--

limestone outcrop prairie

Helianthus maximiliani Schrader--prairies and river

bluffs pasture, R.R. right-of-way, roadsides

Helianthus petiolaris Nutt.--sandy roadsides or waste areas

He1ianthus tuberosus L. var. tuberosus--1imestone outcrop prairie, roadsides, edge of woods

Helianthus tuberosus L. var. subcanescns Gray--same Heliopsis scabra Duva1--shaded edges of roads and woodland edges

Heterotheca latifolia Buckley var. McGregoris Wagen.-sandy or sandstone pastures and roadsides

Hieracium 1ongipilum Torr.--grassland Hymenopappus filifolius Nook.--few found on high limestone grazed pasture 
Hymenopappus tenuifolius Nutt.--numerous on grazed pastures

Iva annua L.--edge salt marsh flats, pastures waterholes, fresh water marsh

Iva xanthifo1ia Nutt.--roadsides, waste areas, edge of woods

Kuhnia eupatorioides L. var. corymbulosa T. \& G.-pastures

Lactuca canadensis L. var. Iongifolia (Michx.) Parw.-edge of and in moist woods

Lactuca 1udoviciana (Nutt.) D.C.--roadsides

Lactuca pulchel1a (Pursh) D.C.--waste places, edges of woods

Lactuca scariola L.--roadsides, waste p1aces, fields

Liatris aspera Michx.--1imestone hills in prairies and grazed pastures

Liatris punctata Hook. var. nebraskana Gaiser--1imestone hills in prairies and grazed pastures

Lygodesmia juncea (Pursh) Duna1--steep roadsides

Lygodesmia rostrata A. Gray--Gates, 1940

Pyrrhopappus grandiflorus Nutt.--few on 1imestone outcrop

Ratibida columnifera (Nutt.) Wooton \& Stand1.--ubiquitous, except very wet areas, especially found on limestone outcrops of overgrazed pastures 
Rudbeckia hirta L.--few on newly planted pasture Rudbeckia triloba L. var. triloba--planted in yards and apparent1y escaping in town

Senecio plattensis Nutt.--1imestone outcrops of grazed pastures

Silphium speciosum Nutt.--prairie

Solidago angustata T.\&G.--Weaver \& Albertson, 1943

Solidago canadensis L. var. scrabra (Muh1.) T.\&G.-pasture

Solidago gigantea Ait.--roadside, river bank, drainage canal

Solidago missouriensis Nutt. var. fasciculata Holz.-prairies, roadsides, and grazed pastures

Solidago mollis Bart1.--roadsides

Solidago petiolaris Ait.--sides of river bluff ravine Solidago rigida L.--1imestone outcrop on pastures Sonchus asper (L.) Hil1--roadsides and waste places Taraxacum erythrospermum Andrz.--grazed pastures, roadsides

Taraxacum officinale Weber--grazed pastures, roadsides, waste p1aces, 1awns

Thelesperma megapotamicum (Spreng.) Kuntze--grazed pastures and prairies

Townsendia exscapa (Richards) Porter--1imestone outcrops in grazed pastures 
Tragopogon dubius Scop.--numerous on roadsides, waste places, some on grazed pastures

Tragopogon porrifolius L.--Gates, 1940

Vernonia baldwini Torr. var. interior (Small)Schub.-grazed pastures

Xanthium pennsylvanicum Wallr.--cultivated fields, waste areas, river bank

Xanthium strumarium. L.--Schaffner (1898)

Convolvulaceae

Convolvulus arvensis L.--fields, roadsides, waste places

Convolvulus interior. House--Gates, 1940

Convolvulus sepium L.--roadsides, edges of fields

Cuscuta Corylí Engelm.--waste places

Cuscuta cuspidata Engelm.--waste places

Cuscuta glomerata Choisy var.neuropetala Hitchc.--found on Salix on river bank

Ipomea hederacea (L.) Jacq.--thickets

Ipomea purpurea (L.) Roth--roadside, creek edge, garien Cornaceae

Cornus drummondi C.A. Meyer--roadsides, thickets, and edge of woods

Cruciferae

Arabis hirsuta (L.) Scop. var. pycnocarpa(Hopkins) Rollins--few at edge of wooded slope 
Brassica kaber L.--fields and roadsides

Camelina microcarpa Andr.--roadsides and waste places

Capse11a bursa-pastoris (L.) Medic.--roadsides, waste p1aces, lawns

Descurania pinnata (Wa1t.) Britt.--roadsides, waste areas, grazed pastures

Descurania sophia (L.) Webb--waste area, pasture, roadsides

Draba reptans (Lam.) Fern.--grazed pastures and prairies Erysimum repandum L.--roadsides, waste places, over grazed pastures

Hesperis matronalis L.--roadsides and occasional in open woods

Lepidium densiflorum Schrader--ubiquitous

Rorippa islandica (Oerder) Borbas--sand bars, border of semi-shaded sma11 stream

Rorippa sessiliflora (Nutt.) Hitchc.--edge of ponds and on sand bars

Rorippa sinuata (Nutt.) Hitchc.--1ow wet places and at edge of ponds

Sisymbrium a1tissimum L.--Gates, 1940

Thlaspi arvense L.--roadsides and waste places Cucurbitaceae

Cucurbita foetidissima H.B.K.--R.R. right-of-ways, waste p1aces 
Sicyos angulatus L.--woods

Cupressaceae

Juniperus virginiana L.--prairie or pasture hillsides Cyperaceae

Carex annectans (Bickn.) Bickn. var. xanthocarpa

(Bickn.) Wieg--saltmarsh prairie

Carex brevior (Dewey) Mack.--pastures and leve1 p1aces of prairie

Carex bushii Mack.--salt marsh prairie, sandstone pastures (in moist areas sometimes)

Carex cepha1ophora Muh1. var. mesochorea (Mack.) G1.-grazed pasture

Carex eleocharis Bailey--river bluffs pasture

Carex granularis Muh1.--shaded stream bank

Carex gravida Bailey--pastures and low prairies

Carex gravida Bailey var. Iunelliana (Mack.) Herm.-s ame

Carex grisea Woh1.--shaded stream bank

Carex heliophila Mack.--one plant found in grazed pasture

Carex hystricina Muh1.--sandstone pasture seepage areas Carex Iasiocarpa Ehrh. var. 1atifolia (Bock) G1.-very wet seepage areas

Carex normalis Mack.--seepage areas

Carex scoparia Schk.--sandstone pasture seepage areas 
Carex stipata Muh1. var. stipata--sandstone pasture seepage area

Carex vulpinoidea Michx.--edge of ponds, low wet, and seepage areas

Carex sparganioides Muh1. var. aggregata (Mack.) G1.-salt marsh prairie

Cyperus erythrorhizus Muh1.--shore of pond

Cyperus ferruginescens Boeck1.--Gates, 1940

Cyperus filiculmis Vah1.--grazed pastures

Cyperus inflexus Muh1.--Gates, 1940

Cyperus schweinitzii Torr.--10w moist soil

Cyperus strigosus L.--10w moist areas and also along roadsides

Eleocharis palustris L.) R.\&S.--10w wet areas in salt marsh, seepage areas, and edge of ponds

Eleocharis wolfii A. Gray--Gates, 1940

Scirpus acutus Muh1.--salt marsh

Scirpus americanus Pers.--fairly large seepage areas and salt marsh

Scirpus atrovirens (Torr.) Gray--seepage and marshy areas

Scirpus fluviatilis (Torr.) Gray--salt marsh and edge of salt marsh 1ake

Scirpus lineatus Michx.--seepage areas and salt marsh Scirpus paludosis Ne1s.--salt marsh

Scirpus validus Vah1.--large seepage areas and salt marsh 
Eleagnaceae

Eleagnus angustifolia L.--few escapes into pastures Equisetaceae

Equisetum hyemale L. var. affine Enge1m.--near pond overflow

Equisetum kansanum Schaeffer--sandy hil1side, draws, low pasture

Equisetum 1aevigatum A. Brown--1ow wet areas but sometimes on drier slopes

Euphorbiaceae

Acalypha rhomboidea Raf.--in draw, along shaded stream bank

Croton capitatus Michx.--in pasture near seepage area

Croton monanthogynus Michx.--semi-wooded grazed low pasture

Croton texensis (K1otzsch) Mue11, Arg--sandy pastures Euphorbia dentata Michx.--disturbed areas and roadsides Euphorbia dictyosperma Fisch. \& Meyer--grazed pasture and lowland prairie

Euphorbia glyptosperma Enge1m.--disturbed areas, grazed pasture

Euphorbia heterophy1la L.--semi-open wooded slope Euphorbia hexagona Nutt.--roadsides in sandy river va11ey

Euphorbia humistrata Engelm.--waste areas, bare spots in pasture 
Euphorbia maculata L.--river bluffs, draws

Euphorbia marginata Pursh.--grazed pastures and waste areas

Euphorbia obtusata Pursh.--Gates, 1940

Euphorbia press1ii Guss.--Gates, 1940

Euphorbia serpens H.B.K.--disturbed areas

Euphorbia supina Raf.--disturbed areas, bare areas in sma11 marsh prairie

Fagaceae

Quercus macrocarpa Michx.--river and creek valleys especially in $\mathrm{NE}$ quarter

Fumariaceae

Corydalis campestris (Britt.) Bushho1s \& Palmer--damp draws, wet roadside

Gramineae

Aegilops cylindrica Host--roadsides

Agropyron desertorum (Fisch.) Schu1t.--river valley roadside

Agropyron smithii Rydb.--roadsides, pastures, occasionally in prairies

Agrostis alba L.--high places in fresh water marsh, low pasture

Agrostis hyemalis (Wa1t.) B.S.P.--thick in sandstone pasture

Alopecurus carolinianus Walt.--Gates, 1940 
Andropogon Gerardi Vitman--roadsides, prairies Andropogon scoparius Michx.--roadsides, prairies Andropogon saccharoides Swartz--roadside of o1d U.S. 81 Aristida oligantha Michx.--overgrazed dry pasture and roadsides

Bouteloua curtipendula (Michx.) Torr.--pastures and prairies

Bouteloua gracilis (H.B.K.) Lag.--pastures Bouteloua hirsuta Lag.--pastures and prairies Bromus inermis Leyss.--roadsides Bromus japonicus Thunb.--pastures, prairies, roadsides Bromus secalinus L.--Gates, 1940

Bromus squarrosus L.--pastures, prairies Bromus tectorum L.--pastures and roadsides Buchloe dactyloides (Nutt.) Engelm.--pastures and occasionally on prairies

Calamovilfa longifolia (Hook.) Scribn.--river bluffs pasture and sandy river valley roadside Cenchrus longispinus (Hackel) Fern.--waste places, river b1uffs pasture, roadsides

Chloris verticillata Nutt.--1awns, gardens, waste places Digitaria sanguinalis (L.) Scop.--1awns, gardens, fields, waste places

Distich1is stricta (Torr.) Rydb.--salt marsh area Echinoch1oa crusgal1i L. var. muricata (Michx.) Farw.-low wet areas 
Ech. crus. L. var. microstachya (Wieg.) Shinners--same Eleusine indica L.--waste area

E1ymus canadensis L. var. brachystachys (Scribn. \& Ba11)

Farwe11--roadsides, salt marsh prairie, waste areas E1ymus canadensis L. var. robustus (Scribn. \& Smith)

Mack. \& Bush--roadsides, waste areas

Elymus virginicus L. var. virginicus--edge draw in low pasture

E1ymus virginicus L. var. jejunis (Rama1ey) Bush--f1oor of woods, salt marsh pasture

Eragrostis cilianensis (A11.) Lutati--roadsides and wasteplaces

Eragrostis hypnoides (Lam.) B.S.P.--Gates, 1940

Eragrostis pectinacea (Michx.) Nees--waste areas and roadsides

Eragrostis pilosa (L.) Beauv.--Gates, 1940

Eragrostis pilifera Scheele--river valley roadside Eragrostis spectabilis (Pursh) Steud.--pastures, roadsides, waste places

Eragrostis trichodes (Nutt.) Wood--Gates, 1940

Eriochloa contracta Hitchc.--wheat stubble

Festuca obtusa Bieler--one clump on semi-open wooded s1ope

Festuca octoflora Walt.--scattered in pastures and prairies

G1yceria striata (Lam.) Hitchc.--seepage areas 
Hordeum jubatum L.--edge of 1 arge seepage areas and on salt marsh

Hordeum pusillum Nutt.--grazed pastures

Koeleria cristata (L.) Pers.--scattered on prairies

Leersia oryzoides (L.) Sqartz--seepage or low wet areas

Leersia virginica Wil1d.--salt marsh drainage canal

Leptoloma cognatum (Schu1t) Chase--sandstone pasture Muhlenbergia asperifolia (Nees \& Mey.) Parod.--sandstone pasture

Muhlenbergia cuspidata (Torr.) Rydb.--dry rocky prairie Muhlenbergia frondosa (Poir.) Fern.--edge salt marsh

flats and along small stream and salt marsh drainage canal

Muhlenbergia mexicana (L.) Trin.--Gates, 1940

Muhlenbergia racemosa (Michx.) B.S.P.--roadsides

Panicum capillare L.--roadsides, waste p1aces, pastures

Panicum dichotomiflorum Michx.--waste areas

Panicum huachucae Ashe.--scattered on sandstone pasture

Panicum scribnerianum Nash.--numerous on sandstone pastures, some on other pastures and prairies, and roadsides

Panicum virgatum L.--salt marsh prairie, river bluffs pasture, prairie

Paspalum ciliatifolium Michx.--sandy pastures and roadsides

Phleum pratense L.--Gates, 1940 
Phalaris arundinacea L.--fresh water marsh

Poa pratensis L.--pastures and prairies

Schedonnardus paniculatis (Nutt.) Tre1.--grazed pasture

Setaria glauca (L.) Beauv.--waste areas, gardens, 1 awns, pastures, roadsides

Setaria viridis (L.) Beauv.--waste areas, gardens, roadsides

Sitanion hystrix (Nutt.) J. G. Smith;-Gates, 1940

Sorghastrum nutans (I.) Nash--prairies, roadsides

Sorghum halepense (L.) Pers.--roadsides

Spartina pectinata Link.--salt marsh, low wet roadsides and pasture

Sphenopholis obtusata (Michx.) Scribn.--grazed pasture, prairie, open flats in river woods

Sporobolus asper (Michx.) Kunth--roadsides, river b1uffs pasture

Sporobolus cryptandrus (Torr.) A. Gray--pastures and roadsides

Sporobolus heterolepis Gray--Schaffner 1898

Sporobolus neglectus Nash.--roadsides, farm yards

Sporobolus texanus Vasey--Schaffner 1898

Tridens flavus (L.) Hitchc. forma cuprea Fosberg--roadside ditches

Hippocastanaceae

Aesculus glabra Willd.--few along driveway in wooded area of county 
Hydrophy11aceae

El1isia nyctelea L.--moist woodlands or low places Hypericaceae

Hypericum mutilum L.--seepage areas in sandstone pasture

Jug1 andaceae

Juglans nigra L.--woodlands along creeks and river Juncaceae

Juncus bufonius L. var, bufonius--sandy shore of spring fed pond in river valley

Juncus interior Wieg.--prairies, pastures, roadsides Juncus marginatus Rostk.--seepage area in sandstone pasture

Juncus tenuis Willd.--edge of seepage area in sandstone pasture

Juncus torreyi Cov.--seepage areas, sand bars

Labiatae

Agastache nepetoides (L.) Ktze.--Gates, 1940

Hedeoma hispidum Pursh.--salt marsh prairie and grazed pastures

Lycopus americanus Muh1.--open woodlands, moist or wet areas

Marrubium vulgare L.--waste places in yards and roadsides

Mentha arvensis L. var. villosa (Benth) S.R. Steward.

forma glabrata. (Genth) S. R. Steward--1ow marshy areas and along streams 
Monarda fistulosa L. var. mollis (I.) Benth.--edge of woods

Nepeta cataria L.--waste places in yards and roadsides Prunella vulgaris L.--in shade of tree in grazed pasture Salvia azurea Lam. var. grandiflora Benth.--roadsides, prairies, and pastures

Salvia reflexa Hornem.--waste places

Scutellaria 1ateriflora L.--seepage area and river bank Scutellaria parvula Michx. var. 1eonardi (Ep1ing) Fern. --low areas in prairies or along seepage areas in pastures

Teucrium canadense L. var. virginicam (L.) Eaton--edge of woods, salt marsh prairie edge, and edge of seepage areas

Leguminosae

Desmanthus illinoensis (Michx.) MacM.--pastures (especially river bluffs) and salt marsh prairie Schrankia nutallii D. C. Stand1--prairies and pastures Cassia marilandica L.--few plants in one woods Cassia fasciculata Michx.--roadsides Gleditsia tricanthos L.--woodlands along creeks and river

Gymnocladus dioica (L.) K. Koch--few in woodlands along creeks and river

Amorpha canescens Pursh.--prairies 
Amorpha fruticosa L. var. augustifolia Pursh--edge of salt marsh, pasture draws

Astragalus canadensis L.--edge of dry stream bed Astragalus caryocarpus Kerr.--1imestone outcrop in grazed pasture

Astragalus lotiflorus Hook.--river bluffs Astragalus missouriensis Nutt.--1imestone hills of grazed pasture

Astragalus plattensis Nutt.--gentle slopes in grazed pasture

Astragalus racemosus Pursh.--sides of river bluff ravines (sha1e)

Crotalaria sagitta1is L.--Gates, 1940

Dalea alopecuroides Willd.--Gates, 1940

Dalea aurea Nutt.--prairies, pastures, and roadsides

Dalea enneandra Nutt.--prairies, and river bluffs pasture

Desmodium il1inoense Gray--roadsides

G1ycyrrhiza 1epidota (Nutt.) Pursh--pastures

Lespedeza capitata Michx.--sandstone or sandy pastures and roadsides

Lotus americanus (Nutt.) Bush--prairies, pastures Medicago 1upulina L.--1awns and in some grazed pastures Medicago sativa L.--roadsides (cultivated and escaped) and waste areas 
Melilotus alba L.--roadsides, high ground in marshes Me1ilotus officina1is (L.) Lam.--roadsides, waste areas, high ground in marshes

Oxytropis 1ambertii Pursh.--river bluffs pasture, and occasional in prairie

Petalostemum candidum (Wi11d.) Michx.--prairies, pastures and roadsides

Petalostemum purpureum (Vent.) Rydb.--prairies and roadsides

Psoralea argophy11a Pursh.--prairies and pastures

Psoralea esculenta Pursh.--few scattered in prairies and pastures

Psoralea 1anceolata Pursh.--Gates, 1940

Psoralea micrantha A. Gray--sandy river valley roadsides Psoralea tenuiflora Pursh.--on some prairies and roadsides

Robinia pseudo-acacia L.--few in pasture, some on roadside escaping cultivation

Strophostyles leiosperma (T.\& G.) Piper--roadsides and grazed pastures

Trifolium reflexum L. var. glabrum Lojoncona--Gates, 1940

Trifolium repens L.--marshes, low areas in pastures Vicia americana Muh1. var. angustifolia Nees.--R.R. right-of-way and pastures 
Vicia oregana Nutt.--Gates, 1940

\section{Lemnaceae}

Lemna minor L.--edges of spring fed ponds and in shallow water of marshes

Lemna perpusilla Torr.--shallow water of marsh

Spirodelia polyrhiza (L.) Schleiden--edges of spring fed ponds and shallow water

\section{Liliaceae}

Allium canadense Michx. var. Fraseri Ownbey--roadside on 1imestone hills

A11ium Drummondi Rege1--prairies and grazed 1imestone pastures

A11ium perdu1ce S. V. Fraser--pastures

Allium sativum L.--one group along roadside Asparagus officinalis L.--few escaped along roadsides and in woods

Polygonatum canaliculatum (Muh1.) Pursh.--woods

Smilacina stellata (I.) Desf.--woods

Smilax tamnoides L. var. hispida (Muh1.) Fern.--woods

Yucca glauca Nutt.--river bluffs pasture

Linaceae

Linum rigidum Pursh.--pastures and salt marsh prairie

Linum sulcatum Ridde11--pastures and prairies

Linum usitatissimum L.--some scattered in alfalfa field

Loasaceae

Mentzelia decapetala (Pursh.) Urban \& Gilg.--river bluff ravines and sandstone roadsides 
Lobe1iaceae

Lobelia siphilitica L.--seepage area in sandstone pasture

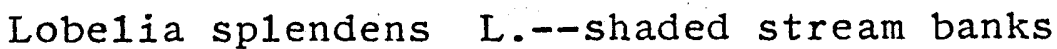

Lythraceae

Ammannia coccinea Rottb.--edge of salt marsh flats and edge of pond

Malvaceae

Abutilon theophrasti Medic.--feed lots, waste areas, semi-wooded pasture and roadsides

Ca11irhoe alcaeoides (Michx.) Gray--pastures and prairies

Ca11irhoe involucrata (T. \& G.) Gray--pastures (prefers sandy ones) and salt marsh prairie

Hibiscus trionum L.--roadsides, cultivated fields Malva neglecta Wa11r.--waste places and back yards

Sida spinosa L.--semi-open woods

Sphaeralcea coccinea (Pursh.) Rydb.--grazed pasture and roadside

Marsileaceae

Marsilea mucronata A.Br.--Gates, 1940

Martyniaceae

Proboscidea 1ouisianica (Mi11) The11--1ow overgrazed pasture

Menispermaceae

Menispermum canadense L.--semi-open woods 
Moraceae

Cannabis sativa L.--10w pasture around creeks and in waste areas

Maclura pomifera (Raf.) C.K. Schneid--widely planted in hedges and escaping

Morus alba L.--woods along river valley

Morus rubra L.--most1y in river valley woods; occasiona11y in creek woods

Najadaceae

Potamogeton foliosus Raf.--spring fed marshes or ponds

Potamogeton nodosus Poir.--spring fed ponds

Potamogeton pectinatus L.--spring fed pond

Zaniche11ia palustrus L. var. major (Boen.) W.D.J. Koch --overflow of spring fed river valley pond

Nyctaginaceae

Mirabilis 1inearis (Pursh.) Heimer1--pastures and roadsides

Mirabilis nyctaginea (Michx.) MacM.--waste p1aces, roadsides

Oleaceae

Fraxinus pennsylvanica Marsh var. Austini Fern.--river val1ey woods

Fraxinus pennsylvanica Marsh var. subintegerrima (Vah1.) Fern.--wood1ands

Onagraceae

Epilobium coloratum Biehler--seepage areas 
Gaura biennis L.--roadsides

Gaura coccinea Pursh.--waste places, sandy pastures, roadsides

Gaura parvif1ora Doug1as--roadsides, river bluffs, sa1t marsh prairie

Oenothera biennis L.--Gates, 1940

Oenothera biennis L. var. hirsutissma Gray--roadsides and waste places

Oenothera laciniata Hil1--sandy pastures, waste places Oenothera missouriensis Sims--1imestone hills of grazed pasture, prairie, and roadsides

Oenothera missouriensis Sims var. incana Torr.--Gates, 1940

Oenothera serrulata Nutt.--pastures, prairies, and roadsides

Oenothera rhombipetala Nutt.--1ow R.R. right-of-way Oenothera speciosa Nutt.--roadsides

Stenosiphon 1inifolius (Nutt.) Britt.--prairies, roadsides

Orchidaceae

Habenaria leucophaea (Nutt.) Gray

Oxalidaceae

Oxalis stricta L.--open woods, also denser woods

Oxalis Dillenii Jacq. ssp. Dillenii--pastures, waste p1aces

Oxa1is violacea L.--prairies, pastures 
Papaveraceae

Argemone intermedia Sweet--roadsides and pastures Phrymaceae

Phryma leptostachya L.--edge of woods

Polyga1aceae

Polygala alba Nutt.--prairies and pastures

Polygala verticillata L.--grazed pastures

Po1ygonaceae

Polygonum aviculare L. var, aviculare--roadsides, edge cultivated fie1ds

Polygonum aviculare L. var. vegatum Ledeb.--damp draw

Polygonum aviculare L. var. 1ittorale (Link) W. D. Kock -water holes in pasture

Polygonum coccineum Muh1. var. pratincola (Greene)

Stanford--roadsides and damp draws

Polygonum coccineum Muh1. var. rigidulum (Sheld) stanford - -sha11ow water of pond

Polygonum convolvulus L.--waste places

Polygonum hydropiperoides Michx. var. strigosum (Sma11)

Stanford--seepage areas

Polygonum lapathifolium I.--salt and frest water marshes and roadside ditches and river bank

Polygonum pennsylvanicum L. var. pennsylvanicum--roadsides, waste places, salt marsh

Polygonum pennsylvanicum L. var. 1aevigatum Fern. forma albineum Farw.--waste places and roadsides 
Po1ygonum pennsy1vanicum L. var. 1aevigatum forma 1aevigatum--salt marsh flats

Polygonum persicaria L. var. ruderale Salisb.--seepage areas and sand bars

Polygonum punctatum E11. var. punctatum--in salt marsh by water hole and along drainage canal

Po1ygonum punctatum E11. var. 1eptostachyum (Meisn.) Sma11--moist waste area

Polygonum ramosissimum Michx.--salt marsh flats

Polygonum scandens L.--roadsides and thickets

Polygonum tenue Michx.--draws and ravine

Rumex altissimus Wood--roadsides, pond edges, salt and fresh water marshes, rivex banks

Rumex alluvius Gates and McGregor--river banks

Rumex crispus L.--same as R. altissimus

Rumex maritimus L.--mud bar at edge river

Polypodiaceae

Woodsia obtusa (Spreng) Torr.--sandstone outcrops (protected)

Pontederiaceae

Heteranthera limosa (S.W.) Willd.--edge of small pond Portulacaceae

Portulaca oleracea L.--sidewalk cracks, cultivated areas Primulaceae

Androsace occidentalis Pursh.--grazed pastures 
Ranunculaceae

Anemone caroliniana L. forma caroliniana--grazed pastures

Anemone caroliniana L. forma violacea Clute--grazed pastures

Delphinium ajacis L.--few escapes along roadside Delphinium virescens Nutt.--prairies, pastures, roadsides

Ranunculus scleratus L.--shallow water from seepage and at edge of ponds

Thalictrum dasycarpum Fisch. \& La11.--at edge of river val1ey woods

Rhamnaceae

Ceanothus ovatus Desf.--roadsides of high 1imestone hills

Ceanothus ovatus Desf. var. pubescens--Gates, 1940

Rhamnus 1anceolata Pursh.--Gates, 1940

Rosaceae

Agrimonia parviflora Ait.--seepage areas in sandstone pastures

Geum canadense Rydb. var. camporum (Rydb.) Fern. \& Weath--wood 1 ands

Potentilla paradoxa Nutt.--fresh water marsh areas Prunus americana Marsh--edge of woods and along roadsides 
Prunus besseyi Bailey--one group on limestone hilltop roadside

Prunus lanata Mack. and Bush--Gates, 1940

Prunus virginiana L.--roadsides as thickets

Prunus virginiana L. var. melanocarpa (A. Ne1s.) Sarg.-Gates, 1940

Rosa arkansana Porter var. suffulta (Greene) Cockere11-roadsides and waste areas

Rubus occidentalis L.--edge of woods and on one east facing road cut

Rubiaceae

Cephalanthus occidentalis L.--one plant in prairie bordering salt marsh 1ake

Galium aparine L.--woods or in shaded areas

Galium circaezans Michx. var. hypomalacum Fern.--in a wooded sloping draw (one patch)

Hedyotus nigricans (Lam.) Fern.--pastures and prairies Rutaceae

Zanthoxy1um americanum Mi11.--edge of woods and in river bluff ravines

Salicaceae

Salix amygdaloides Anderss.--along river, streams, and 1arge seepage areas

Salix interior Rowlee--river banks, sandbars

Salix eriocephala Michx.--Gates, 1940

Salix nigra Marsh.--river banks 


\section{Santalaceae}

Commandra umbel1ata (L.) Nutt.--Weaver and Albertson, 1943

Sapindaceae

Cardiospermum halicacabum L.--Gates, 1940

Saxifragaceae

Ribes missouriense Nutt.--wood1ands and thickets

Ribes odoratum Wend1and--roadsides

Penthorum sedoides L.--shaded stream bank

Scrophu1ariaceae

Gerardia aspera Doug1.-- grazed pasture

Gerardia tenuifolia Vah1. var. macrophy11a Benth.-grazed pastures

Lindernia anagallidea (Michx.) Penne11--river sandbar

Lindernia dubia (L.) Penne11--Gates, 1940

Bacopa rotundifolia (Michx.) Wettst--shallow water of pond

Mimulus ringens L.--10w wet shaded area near stream Penstemon Cobaea Nutt.--1imestone prairies and pastures Penstemon digitalis Nutt.--old milo field. (adventive?) Verbascum blattaria L.--roadside

Verbascum thaspus L.--roadsides, pastures, waste places Veronica peregrina L. var. xalapensis (H.B.K.) St. John and Warren--1ow wet areas, edge of sma11 stream, and waste p1aces 
Solenaceae

Datura stramonium L.--edge of cultivated fields, few on salt marsh

Lycium halimifolium Mil1.--cultivated and is escaping along roadside

Physalis angulata L.--semi-wooded pasture area

Physalis hederaefolia Gray var. comata Rydb.--river bluffs pasture

Physalis hederaefolia Gray var. hederaefolia--river bluffs pasture, edge of field in shade

Physalis heterophylla Nees--edge of woods or shaded areas, and river bluffs

Physalis virginiana Miller. var. sonorae (Torr.)

Waterfal1--roadsides, waste places

Solanum americanum Mil1.--woodlands or shaded banks

Solanum carolinense L. var. albiflorum Benke--pastures, waste places

Solanum carolinense L. var. carolinense--pastures and waste piaces

Solanum eleagnifolium Cav.--roadside in sandstone section

Solanum interius Rydb.--river valley roadside ditch and in shade in sandstone pasture

Solanum rostratum Duna1:--disturbed areas, waste places

Solanum triflorum Nutt.--Gates, 1940 
Sparganiaceae

Sparganium eurycarpum Engeh.--10w wet draw and edge sma11 stream

Tamaricaceae

Tamarix pentandra Pa11.--some on salt marshes

Populus alba L.--escaping from plantings

Pópulus deltoides Marsh--along river banks, some along creeks, sma11 ones on salt marsh

Populus sargentii Dode--along rivers and creeks

Tiliaceae

Tilia americana L.--Gates, 1940

Typhaceae

Typha angustifolia L.--colonies on salt marsh

Typha latifolia L.--fresh water and salt marshes

U1maceae

Celtis occidentalis I. var. occidentalis--woodlands and ravines

Celtis occidentalis I. var. pumila (Pursh) Gray--wood1ands and ravines

U1mus americana L.--along creeks and rivers

U1mus rubra Muh1.--a1ong draws, creeks, and rivers Umbe11iferae

Berula pusilla (Nutt.) Fern--spring fed marshy areas

Cicuta maculata L.--fresh water marshes or low moist ground 
Conium maculatum L.--edges of woods and thickets and on 1ow moist areas

Lomatium foeniculatum (Nutt.) C. \& R.--prairies and pastures

Lomatium orientale Coult \& Rose--Weaver \& Albertson, 1943 Pastinaca sativa L.--one found by railroad spur in town Sanicula canadensis L'.--woods

Spermolepis inermis (Nutt.) Nutt. \& Const.--pastures and salt marsh prairie

Urticaceae

Parietaria pennsylvanica Muh1.--woodland floors

Pilea pumila (L.) Gray--seepage area in sandstone pasture

Urtica dioica L. var. procera Wedd.--woodland edges, wood 1 ands, low areas

Verbenaceae

Lippia cuneifolia (Torr.) Steud.--Gates, 1940

Verbena bipinnatifida Nutt.--basically on roadsides and grazed limestone pastures

Verbena bracteata Lago \& Rodr.--1awns and waste places

Verbena hastata L.--draws and seepage areas

Verbena simplex Lehm.--Gates, 1940

Verbena stricta Vento--grazed pastures and roadsides

Verbena stricta Vent. forma roseiflora Benke--grazed pasture 
Verbena stricta Vent. forma alba Wadmond--grazed pasture

Verbena urticifolia L.--edge of woods

$\mathrm{X}$ Verbena Rydbergii Mold.--edge of seepage areas, along semi-wooded stream

$\mathrm{X}$ Verbena Engelmannii Mold.--along semi-wooded stream

$\mathrm{X}$ Verbena illicita Mold.--along semi-wooded stream

$\mathrm{X}$ Verbena moechina Mold.--one plant in sandstone pasture seepage area (compared with Britton and Brown)

Violaceae

Viola papilionacea Pursh.--woodlands and sometimes on north facing draw slopes

Viola bicolor Pursh.--grazed pasture slopes

Vitaceae

Parthenocissus quinquefolia (L.) Planch--woodlands and thickets

Parthenocissus vitacea (Kneer) Hitche.--Gates, 1940

Vitis riparia Michx.--woodlands or thickets, or on single trees

Zygophy11aceae

Tribulus terrestris L.--roadsides, fields, waste places, yards 
1. Fernald, M. L., Grays Manual of Botany, 8th Ed., American Book Co., New York, 1950

2 Gleason, Henry A., An Illustrated Flora of the Northeastern United States and Adjacent Canada, 3rd Ed., Lancaster Press, Lancaster, Pennsy Ivania

3. Hitcheock, A.S. (Revision by Agnes Chase) Manual of the Grasses of the U.S.; Misc. Pub. 200, U. S. Dept. of AgricuIture, WashIngton D。C., , 1951.

4. Rydberg, P. A. Flora of the Prolries and Plains of Central North America, New York BotanicaI Gardens, 1932.

5. Savage, I.0.., A History of Republic County, Kansas, Jones and Chubbre, Art Printers, Belo1t, Kansas, 1901.

\section{Publications}

6. Climate of Kansas, Report of the Kansas State Board of Agriculture, I948, Physical Land CondItIons Affecting Use, Conservation, and Management of Land Resources; Republ1c County, Kansas; Issued by U.S.D.A., Solls Conservation Service, and Kansas Agricultural Expos1tion St. Oct. 1951.

7. Fishel, V. C., Ground Water Resources of Republ1c County and Northern Cloud County, Kansas; University of Kansas Publications, State Geological Survey of Kansas, Bulle$\operatorname{tin} 73$, 1948 .

8. Gates, Frank C., Grasses in Kansas, Kansas State Board of Agriculture Report for 1936 .

9. Gates, Frank C. Flora of Kansas, Contribution No. 391, Department of Botany, Kansas State College, 1940.

10. H1tchcock, A. J., The Plora of Kansas Maps. 1899

11. Shaffner, John H., Notes on the Salt Marsh Plants of Northern Kansas, Botanical Gazette Vol. $25, \mathrm{pp} . \frac{1}{255-260 .}$

12. Weaver, $J_{0} E_{0}$ and $F . W_{0}$ Albertson, Resurvey of Grasses, Forbs, and Underground Plant Parts at the End of the areat Drought, Ecological Monographs, Vol。 $13, \frac{19}{1943 .}$ 
Newspapers

13.. Belleville (Kansas) Telescope, June 30, 1960 - August 18, 1960 